\title{
Nitro-Hydrolysis: An Energy Efficient Source Reduction and Chemical Production Process for Wastewater Treatment Plant Biosolids
}

January 2003

\author{
Prepared by \\ K. Thomas Klasson \\ Robert M. Counce \\ Larry W. Perkins \\ Sadie R. Drescher \\ Charles J. Perilloux
}




\title{
DOCUMENT AVAILABILITY
}

Reports produced after January 1, 1996, are generally available free via the U.S. Department of Energy (DOE) Information Bridge:

Web site: http://www.osti.gov/bridge

Reports produced before January 1,1996, may be purchased by members of the public from the following source:

\author{
National Technical Information Service \\ 5285 Port Royal Road \\ Springfield, VA 22161 \\ Telephone: 703-605-6000 (1-800-553-6847) \\ TDD: 703-487-4639 \\ Fax: 703-605-6900 \\ E-mail:info@ntis.fedworld.gov \\ Web site: http://www.ntis.gov/support/ordernowabout.htm
}

Reports are available to DOE employees, DOE contractors, Energy Technology Data Exchange (ETDE) representatives, and International Nuclear Information System (INIS) representatives from the following source:

Office of Scientific and Technical Information

P.O. Box 62

Oak Ridge, TN 37831

Telephone: 865-576-8401

Fax: 865-576-5728

E-mail: reports@adonis.osti.gov

Web site: http://www.osti.gov/contact.html

This report was prepared as an account of work sponsored by an agency of the United States Government. Neither the United States government nor any agency thereof, nor any of their employees, makes any warranty, express or implied, or assumes any legal liability or responsibility for the accuracy, completeness, or usefulness of any information, apparatus, product, or process disclosed, or represents that its use would not infringe privately owned rights. Reference herein to any specific commercial product, process, or service by trade name, trademark, manufacturer, or otherwise, does not necessarily constitute or imply its endorsement, recommendation, or favoring by the United States Government or any agency thereof. The views and opinions of authors expressed herein do not necessarily state or reflect those of the United States Government or any agency thereof. 
ORNL/TM-2003/3

\title{
NITRO-HYDROLYSIS: AN ENERGY EFFICIENT SOURCE REDUCTION AND CHEMICAL PRODUCTION PROCESS FOR WASTEWATER TREATMENT PLANT BIOSOLIDS
}

\author{
K. Thomas Klasson \\ Robert M. Counce \\ Larry W. Perkins \\ Sadie R. Drescher \\ Charles J. Perilloux
}

Date Published: January 2003

Prepared by

OAK RIDGE NATIONAL LABORATORY

P.O. Box 2008

Oak Ridge, Tennessee 37831-6285

managed by

UT-Battelle, LLC

for the

U.S. DEPARTMENT OF ENERGY

under contract DE-AC05-00OR22725 



\section{CONTENTS}

2.





\section{LIST OF FIGURES}

Figure

Page

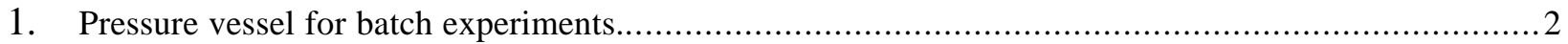

2. Pressure vessel for batch experiments with cap for gas collection........................................ 3

3. A deep fryer (National Presto Industries, Inc., Eau Claire, WI) was used as an oil bath during experimentation.

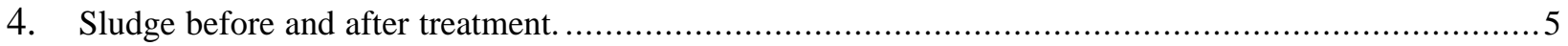

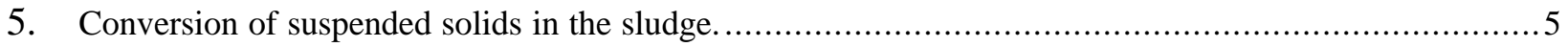

6. Conversion of nitric acid as a function of reaction time and initial amount of nitric acid added............. 6

7. Formic acid production as a function of reaction time and amount of nitric acid added.................... 7

8. Acetic acid production as a function of reaction time and amount of nitric acid added..................... 8

9. Propionic acid production as a function of reaction time and amount of nitric acid added................... 8

10. Butyric acid production as a function of reaction time and amount of nitric acid added.................... 9

11. Yield of carbon in organic acids as a function of the nitric acid consumption.............................. 10 



\section{EXECUTIVE SUMMARY}

The nitro-hydrolysis process has been demonstrated in the laboratory in batch tests on one municipal waste stream. This project was designed to take the next step toward commercialization for both industrial and municipal wastewater treatment facility (WWTF) by demonstrating the feasibility of the process on a small scale. In addition, a 1-lb/hr continuous treatment system was constructed at University of Tennessee to treat the Kuwahee WWTF (Knoxville, TN) sludge in future work. The nitro-hydrolysis work was conducted at University of Tennessee in the Chemical Engineering Department and the gas and liquid analysis were performed at Oak Ridge National Laboratory.

Nitro-hydrolysis of sludge proved a very efficient way of reducing sludge volume, producing a treated solution which contained unreacted solids (probably inorganics such as sand and silt) that settled quickly. Formic acid was one of the main organic acid products of reaction when larger quantities of nitric acid were used in the nitrolysis. When less nitric acid was used formic acid was initially produced but was later consumed in the reactions. The other major organic acid produced was acetic acid which doubled in concentration during the reaction when larger quantities of nitric acid were used. Propionic acid and butyric acid were not produced or consumed in these experiments.

It is projected that the commercial use of nitro-hydrolysis at municipal wastewater treatment plants alone would result in a total estimated energy savings of greater than 20 trillion Btu/yr. A net reduction of 415,000 metric tons of biosolids per year would be realized and an estimated annual cost reduction of $\$ 122 \mathrm{M} / \mathrm{yr}$. 



\section{ACKNOWLEDGMENTS}

This work was supported by the Oak Ridge National Laboratory's State Partnership Program and administered by U.S. Department of Energy's Energy Efficiency and Renewable Energy Program. K. T. Klasson is an Oak Ridge National Laboratory staff member, R. M. Counce is an Oak Ridge National Laboratory staff member and a professor at the University of Tennessee in Knoxville, L. W. Perkins is a graduate student in the Chemical Engineering Department at University of Tennessee, and S. R. Drescher is a student intern at Oak Ridge National Laboratory. Dr. C. J. Perilloux of DuPont Company served as technical advisor to this work. 



\section{INTRODUCTION}

Ninety-nine thousand tons ( $2000 \mathrm{lb} / \mathrm{ton})$ of biosolids, organic residuals from primary settling and biological treatment, are produced each day at wastewater treatment facilities (WWTF) in the U.S. Approximately onethird of the biosolids, 33,000 tons/day, generated by large industrial and municipal WWTF is presently incinerated. ${ }^{1}$ The remainder is used beneficially, land applied, or discharged to the ocean. The amount of biosolids treated by incineration, an energy-intensive method, is likely to increase in the future as stricter regulations reduce traditional disposal options such as land application and ocean disposal.

The DuPont Company has recently discovered the "Nitro-Hydrolysis" sludge destruction technology, which is based on nitric-acid catalyzed hydrolysis of biosolids,

$$
\mathrm{HNO}_{3}+\text { Sludge } \rightarrow \text { Biodegradable materials }+\mathrm{N}_{2} \text {. }
$$

Laboratory studies performed by DuPont on industrial biosolids verified that greater than $90 \%$ conversion of the biosolids was achieved. ${ }^{2}$ This means that greater than $90 \%$ of the biosolid was converted to a biodegradable material. This biodegradable material may be recycled back to the wastewater treatment process where oxidation to $\mathrm{CO}_{2}$ and water is achieved, similar to oxidation of other carbon-based materials. The use of this technology reduces the biosolids discharged from a wastewater treatment to less than $10 \%$ of that originally produced. Any residual nitric acid may be biologically converted to $\mathrm{N}_{2}$ and $\mathrm{H}_{2} \mathrm{O}$. ${ }^{3}$

Nitro-hydrolysis is potentially applicable to sludge from industrial and municipal sources, and therefore, substantially reduces the volume of residuals from biological wastewater treatment requiring disposal/incineration. DuPont has interest in using the nitro-hydrolysis process in the future to treat their industrial waste, but they recognize the tremendous potential benefit for use at large-scale municipal WWTF. They, therefore, offered to collaboratively develop the process for commercialization through a royalty-free license for municipal and industrial companies. DuPont will retain the rights to worldwide use of the technology at their facilities.

\section{ENERGY, ENVIRONMENTAL, AND ECONOMIC BENEFITS OF NITRO HYDROLYSIS}

Several incentives for use of nitro-hydrolysis exist in the arenas of energy, environment, jobs and tangible economics. Management of 99,000 tons/day of biosolids accounts for up to $50 \%$ of the total water treatment costs in the U.S. ${ }^{4}$ There are presently 740 large-scale municipal wastewater treatment systems (treating greater than 10 million gallons per day), which produce biosolids at a rate of $4450 \mathrm{lb} / \mathrm{Mgal}{ }^{1}$. For these facilities, nitro-hydrolysis would reduce the volume of biosolids exiting the WWTF by $90 \%$, and thus reduce the amount of biosolids requiring treatment and disposal. This yields estimated energy savings in natural gas and electricity of 34.6 billion BTU/year and 49 billion BTU/year (total: 84 billion BTU/year) compared to incineration for each of the $740 \mathrm{WWTF}$ presently utilizing incineration as a primary treatment option. Commercial use of nitro-hydrolysis at these plants alone results in a total estimated energy savings of greater than 20 trillion Btu/yr. This results in a net reduction of 415,000 metric tons of biosolids per year, and an estimated annual cost reduction of $\$ 122 \mathrm{M} / \mathrm{yr}$. The extra load on the WWTF would be related to the treatment of the liquid from the sludge treatment and would only contribute $1.5-2 \%$ to the total flow through the system. For a large-scale WWTF the capital cost would be in the range of $\$ 2 \mathrm{M}$. Nitric acid use of 0.2 ton/ton sludge is anticipated. There is a potential for recovering value-added products from the treated sludge. It has been estimated that $178 \mathrm{~kg}$ formic acid and $325 \mathrm{~kg}$ acetic acid may be recovered from treating one metric ton of dry sludge. ${ }^{3}$ The value of these products is $\$ 1.03 / \mathrm{kg}$ of formic acid and $\$ 0.60 / \mathrm{kg}$ of acetic 
$\operatorname{acid}^{5}$ and the annual value of recovering these chemicals is $\$ 163 \mathrm{M} / \mathrm{yr}$ from large-scale treatment systems presently using incineration.

\section{BRIEF PROJECT DESCRIPTION}

The nitro-hydrolysis process has been demonstrated in the laboratory in batch tests on one municipal waste stream. This project was designed to take the next step toward commercialization for both industrial and municipal WWTF by demonstrating the feasibility of the process on a small scale. In addition, a 1-lb/hr continuous treatment system was constructed to treated larger volumes of sludge from the Knoxville, TN, Kuwahee WWTF in a future demonstration. The nitro-hydrolysis work was conducted at University of Tennessee in the Chemical Engineering Department and the gas and liquid analysis were performed at Oak Ridge National Laboratory.

\section{MATERIALS AND METHODS}

The nitro-hydrolysis was performed in small stainless steel vessels constructed from 3/4-inch 316 stainless steel tubing (Fig. 1). Initial experiments were conducted with identical capped ends. Later, additional caps were fabricated allowing temperature to be measured or gas to be collected (Fig. 2). The volume of the vessel was $25 \mathrm{~mL}$. During experimentation, the pressure vessels were placed in an oil bath (Fig. 3).

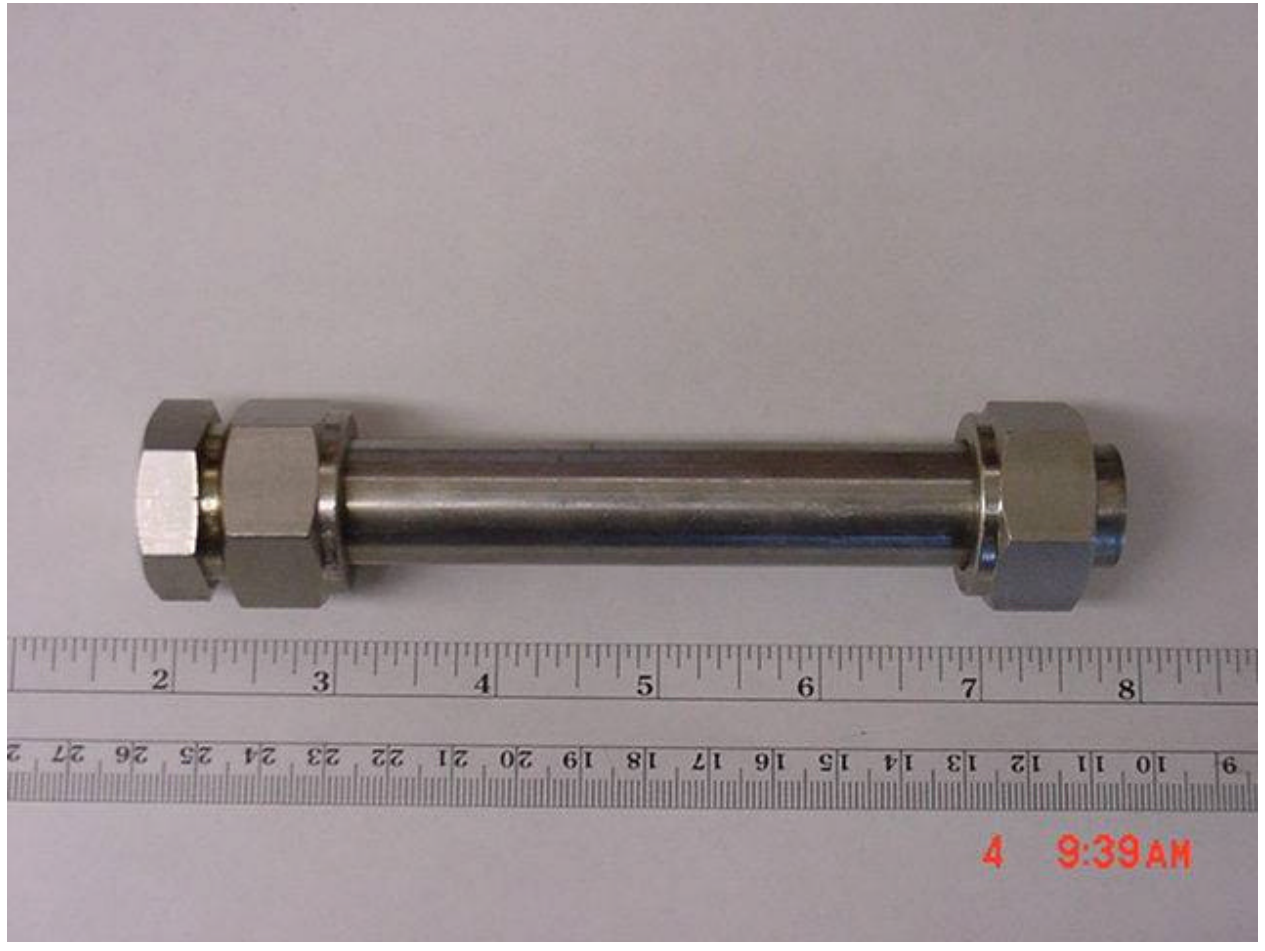

Fig. 1. Pressure vessel for batch experiments. 


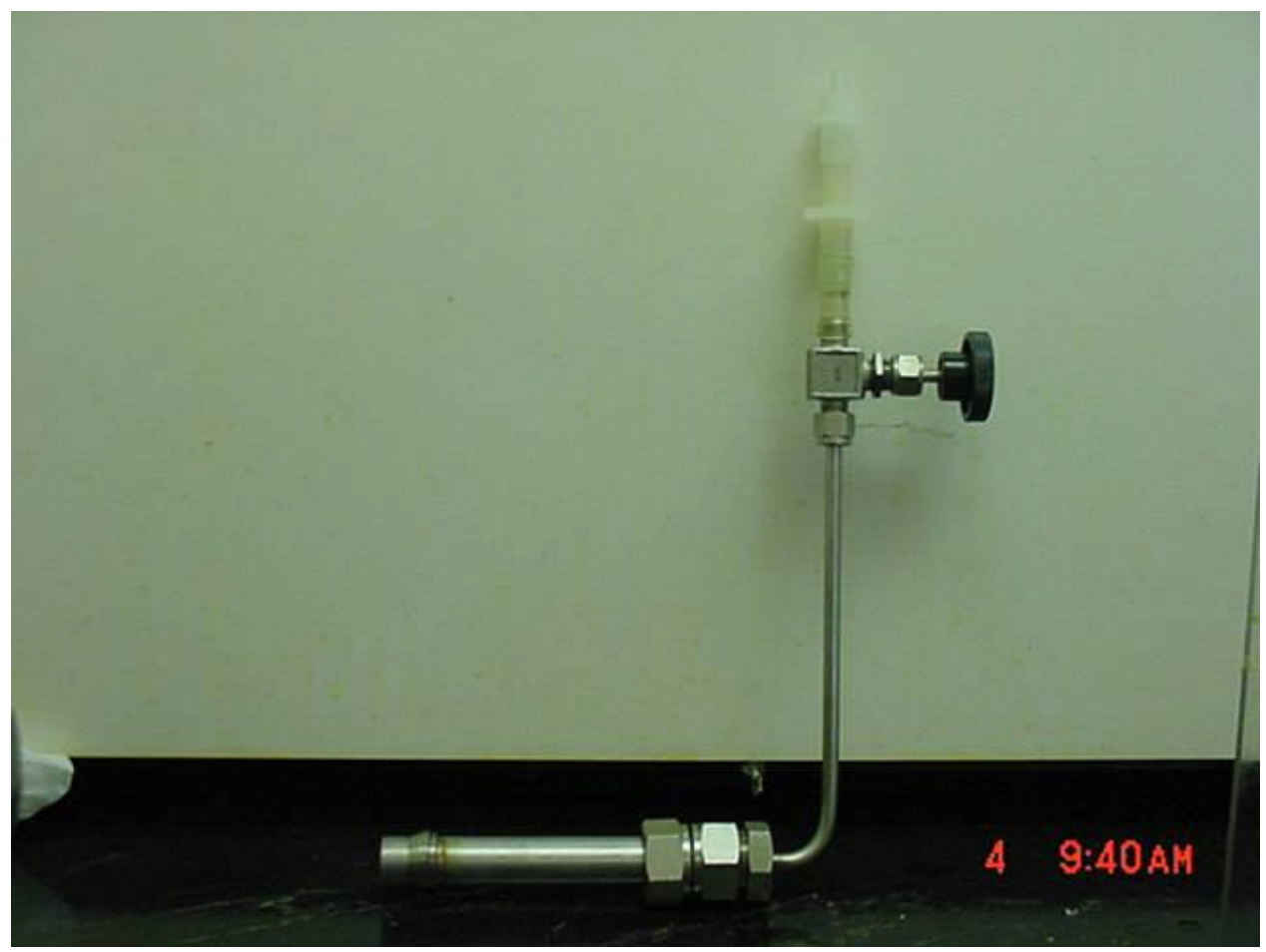

Fig. 2. Pressure vessel for batch experiments with cap for gas collection.

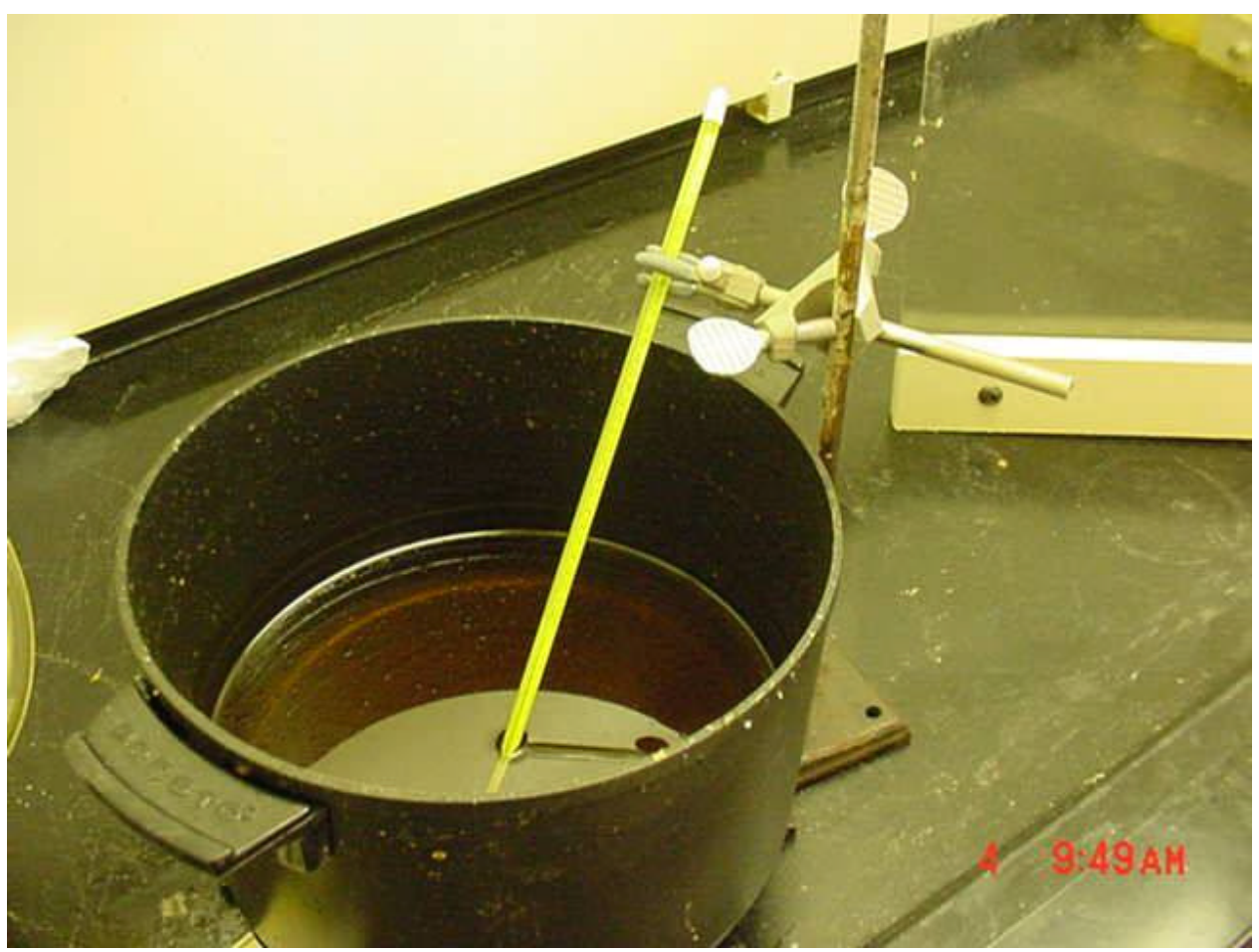

Fig. 3. A deep fryer (National Presto Industries, Inc., Eau Claire, WI) was used as an oil bath during experimentation. 
The sludge used for the experiment was collected from the Knoxville Utility Board Kuwahee Wastewater Treatment Facility in Knoxville, TN. The sludge was collected as a mixture from primary and secondary treatment and contained $4.1 \%$ (by weight) of total solids and 3.9\% of suspended solids. An elemental analysis performed on the total solids by Galbraith Laboratories, Inc. (Knoxville, TN) showed the composition to be $41 \%$ carbon, $17 \%$ nitrogen, $21 \%$ oxygen, $12 \%$ hydrogen, and $9 \%$ others.

A typical experiment consisted of placing approximately $19 \mathrm{~g}$ of wet sludge and a known amount of concentrated nitric acid in the pressure vessel and placing it into the preheated $\left(180^{\circ} \mathrm{C}\right)$ oil bath. The reaction time was recorded, beginning 2 minutes into the experiment. At a predetermined time, the vessel was removed and placed in an ice batch for $5 \mathrm{~min}$. The content was transferred to a volumetric cylinder and the solids were allowed to settle.

Approximately 5-mL of the liquid was gravity filtered through filter paper (No. 5, Whatman International, Maidstone, England)) and sent for liquid analysis. Organic acids (formic, acetic, propionic, butyric, and valeric acids), and nitrate analyses were performed using high pressure liquid chromatography. The mobile phase (filtered $5 \mathrm{mM} \mathrm{H}_{2} \mathrm{SO}_{4}$ ) was pumped at $0.6 \mathrm{~mL} / \mathrm{min}$ through a $300 \mathrm{~mm} \times 7.8 \mathrm{~mm}$ (8- $\mu \mathrm{m}$ particle size) RHM monosaccharide column (Phenomenex, Torrance, CA) held at a temperature of $65^{\circ} \mathrm{C}$. A refractive index detector (Model 240, Waters Corporation, Milford, MA) held at $40^{\circ} \mathrm{C}$ was used for analysis. Each sample was pre-filtered using an Acrodisc LC 13-mm syringe-filter with 0.2- $\mu \mathrm{m}$-pore-size PVDF membrane (Pall Corporation, Ann Arbor, MI). The sample injection volume was $10 \mu \mathrm{L}$ and the resulting chromatograms were compared with injections of acids and nitrate standards.

The remaining contents of the reactor vessel were vacuum filtered through a fritted disk funnel. The solids and the solids collected in the gravity filtration (see above) were then allowed to dry and the fraction of solids consumed in the reaction determined by drying at $105^{\circ} \mathrm{C}$ over night.

The experiments were carried out in triplicates, which allowed for an estimation of experimental error. The standard deviation was estimated using Equation 2 and the method outlined by Taylor. ${ }^{6}$

$$
s=\left(R_{1}+R_{2}+\ldots+R_{k}\right) /\left(k d_{2}^{*}\right)
$$

Where $s$ is the standard deviation, $R_{i}$ is the range of values within a triplicate experiment, $k$ is the number of sets (of triplicate) experiments in a group, and $d_{2}{ }^{*}$ is constant that depends on the degrees of freedom in a group of sets. The experiments were divided into four groups, with assumed respective equal error; the 3-5 min-reaction-time group, 10-min-reaction-time group, the 15-min-reaction-time group, and the 20-minreaction-time group. The standard deviation was then determined for the experiments within each group.

\section{RESULTS AND DISCUSSION}

The overall conversion of sludge solids was very successful from a visual standpoint (Fig. 4). The treated sludge separated very quickly and the solids settled to the bottom. This finding is supported by previous studies which showed that the filterability of the sludge improves with hydrolysis. ${ }^{2}$ 

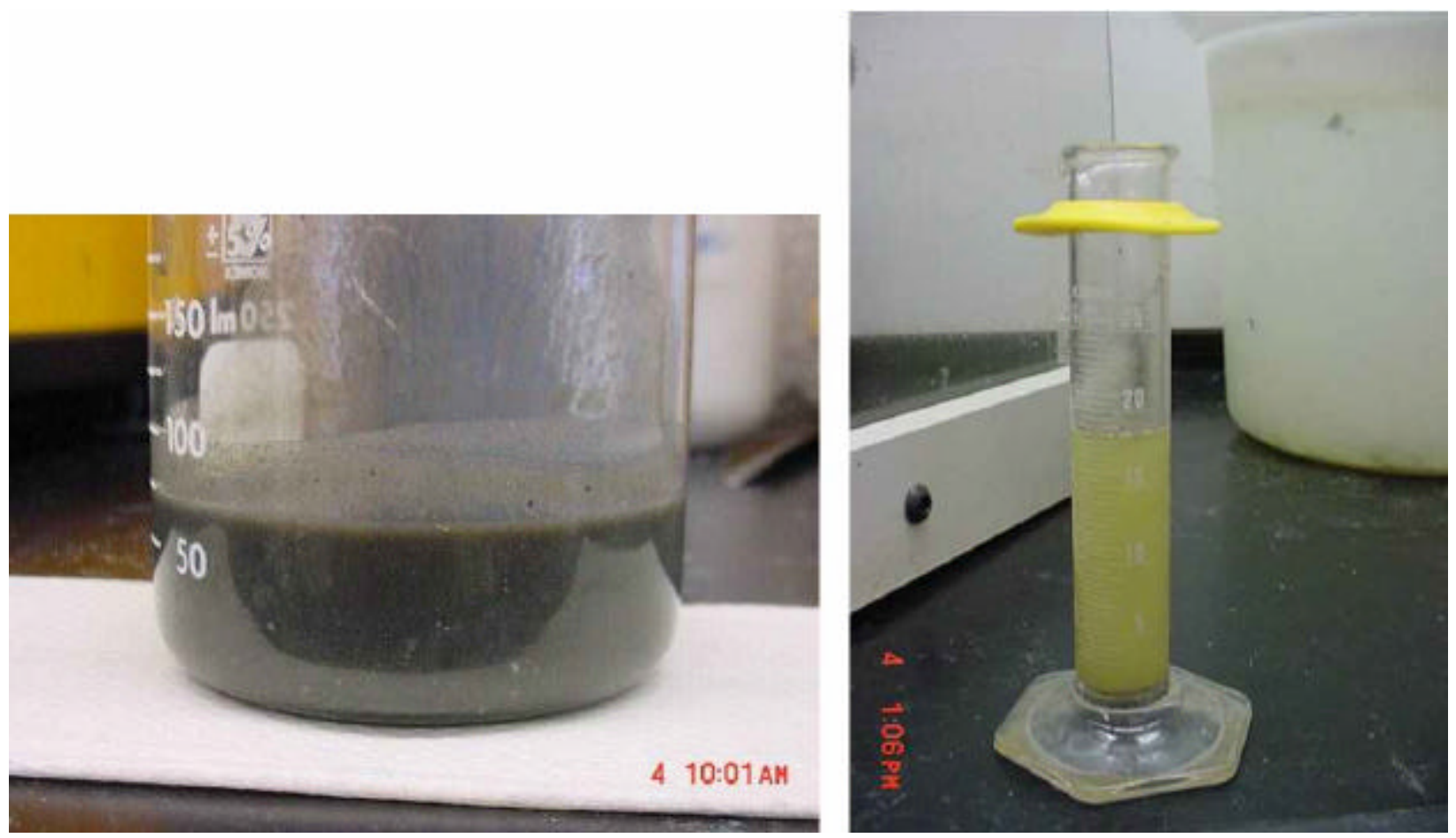

Fig. 4. Sludge before and after treatment.

No clear pattern was noted when the conversion of sludge was plotted as a function of the reaction time for the different nitric acid levels (Fig. 5). However, in general the conversion was greater when a larger amount of nitric acid was used. On average, about $55 \%$ of the suspended solids were converted in the experiments for the conditions shown in Fig. 5.

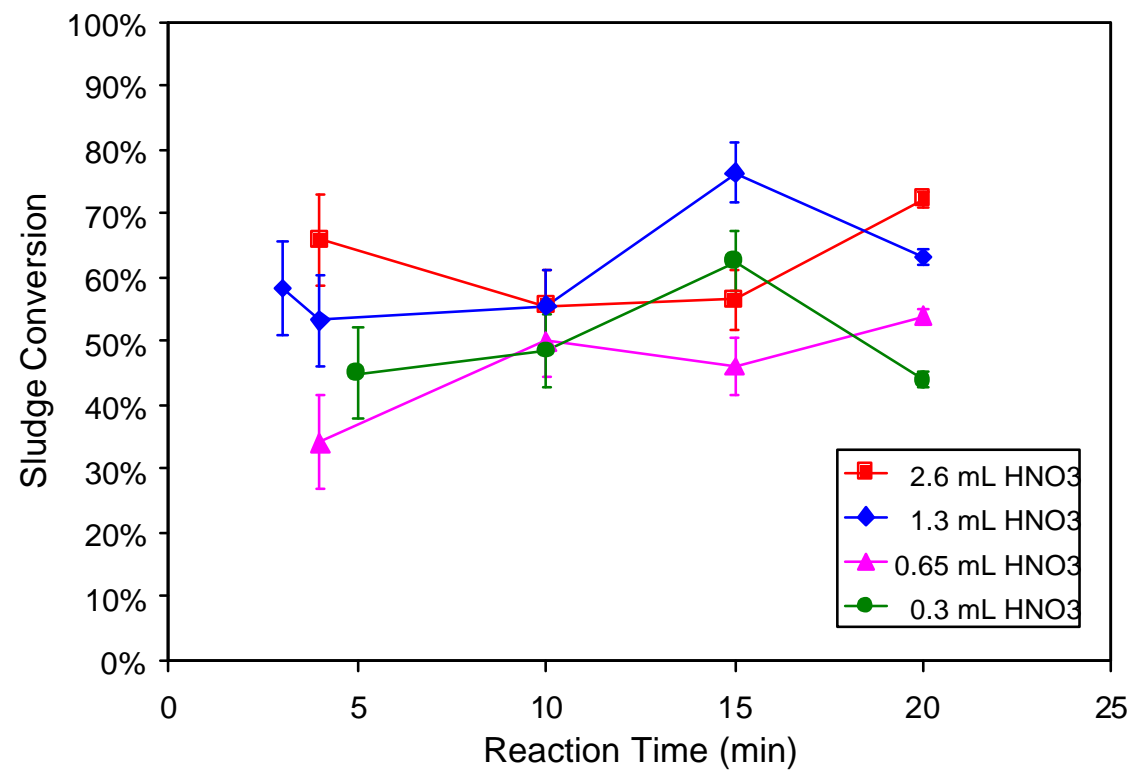

Fig. 5. Conversion of suspended solids in the sludge. The error bars correspond to one (1) standard deviation.

The conversion of nitric acid in the reaction (Equation 1) was determined by comparing the amount of nitric 
acid added and the amount of nitrate remaining after the reaction. As is noted in Fig. 6, higher conversion was noted when less acid was added.

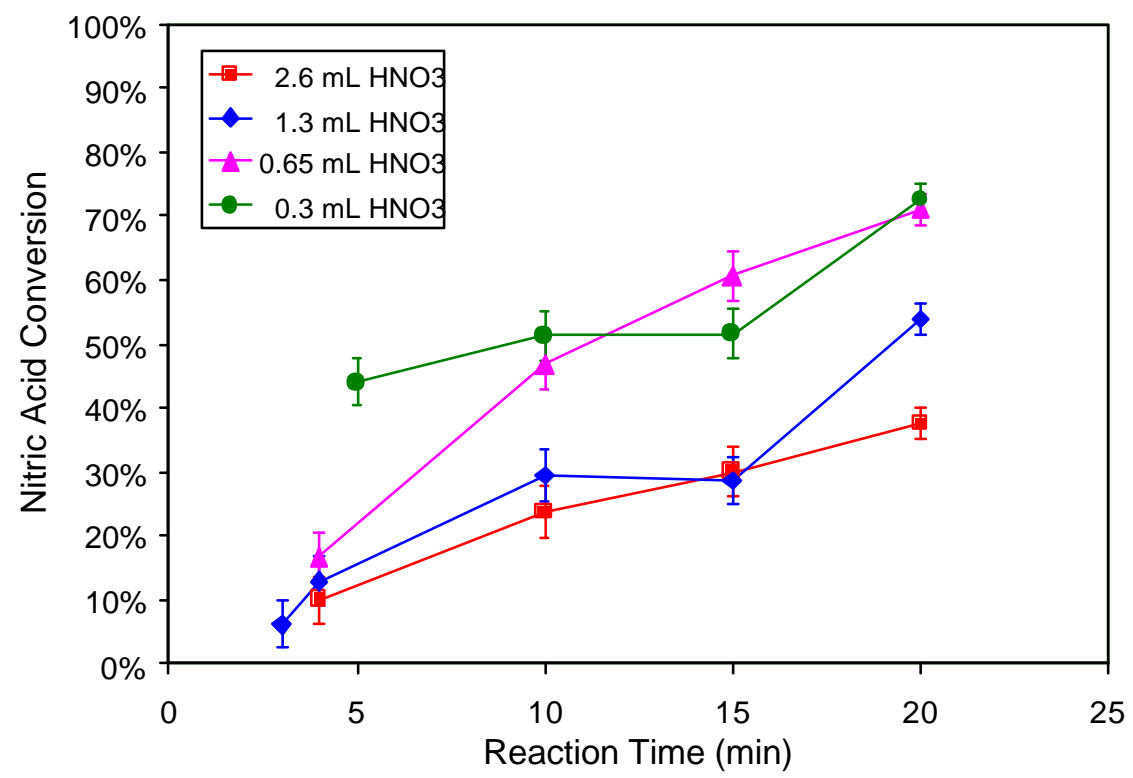

Fig. 6. Conversion of nitric acid as a function of reaction time and initial amount of nitric acid added. 
The organic acids production was measured as function of time for the different nitric acid levels, When low levels of nitric acid were added, the formic acid concentration decreased with time (Fig. 7). At the higher concentrations of nitric acid, formic acid was produced throughout the reaction. The highest concentration of formic acid $(1 \mathrm{~g} / \mathrm{L})$ was found after 20 min reaction time when $2.6 \mathrm{~mL}$ nitric acid was initially added.

Higher concentration of nitric acid also resulted in higher concentration of acetic acid in the treated sludge. The highest concentration of acetic acid $(2.4 \mathrm{~g} / \mathrm{L})$ was recorded after 15-20 min reaction time when $2.6 \mathrm{~mL}$ nitric acid was initially added. This corresponds to twice the amount initially present in the sludge. At the lowest level of nitric acid used in these experiments, the acetic acid concentration did not change during the hydrolysis.

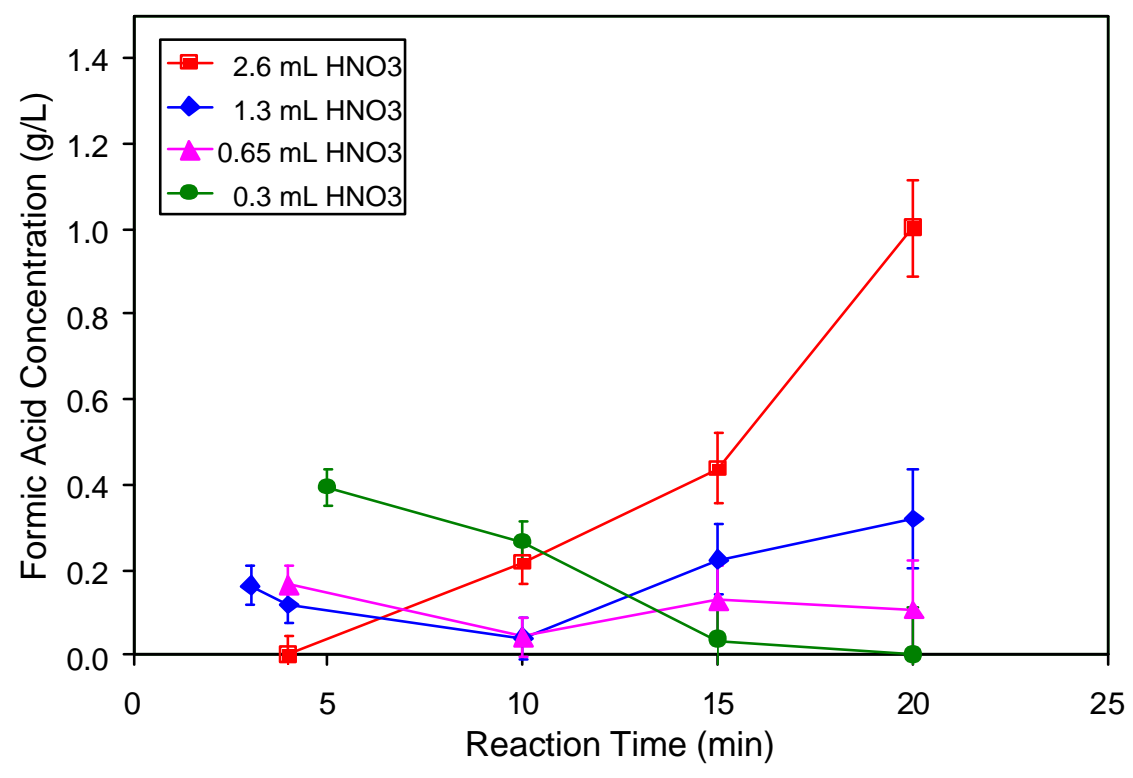

Fig. 7. Formic acid production as a function of reaction time and amount of nitric acid added. There was no formic acid in the sludge before treatment. 


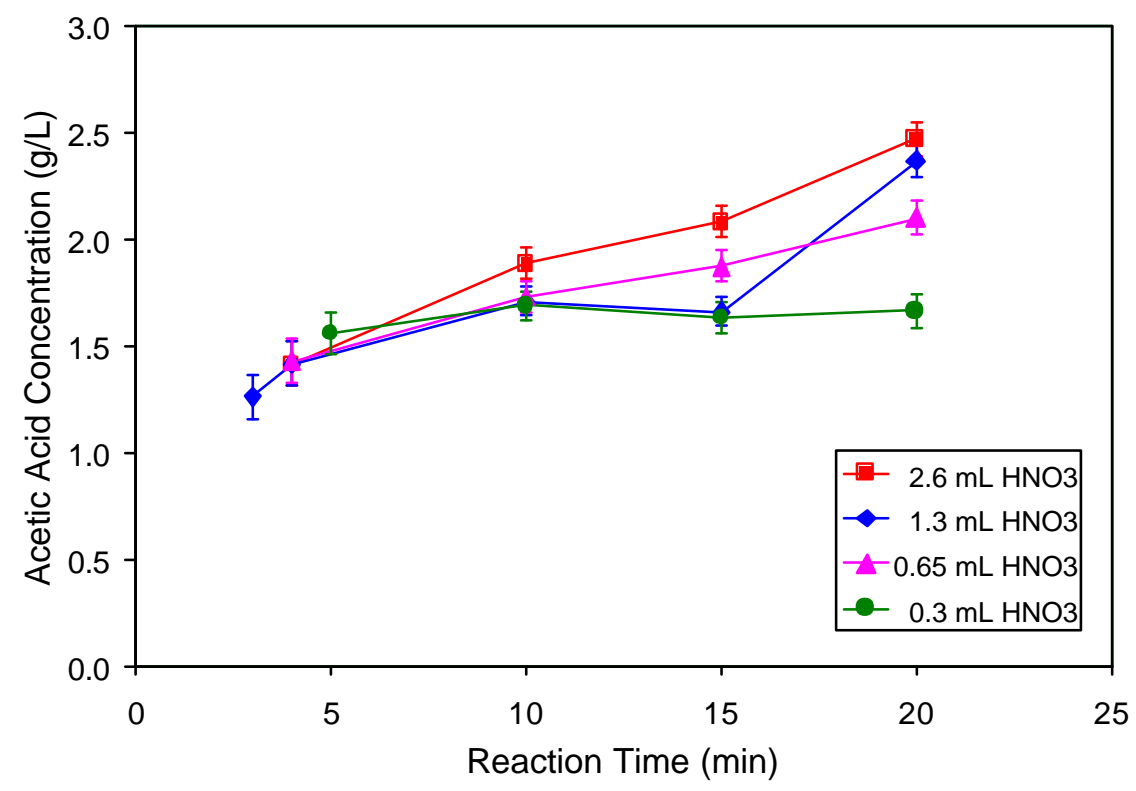

Fig. 8. Acetic acid production as a function of reaction time and amount of nitric acid added. The concentration of acetic acid in the untreated sludge was approximately $1.2 \mathrm{~g} / \mathrm{L}$.

Propionic was not produced above the initial concentration present in the untreated sludge (Fig. 9). The butyric acid concentration under various conditions showed some variation, but it is inconclusive whether or not there was any net production above the initial value (Fig. 10).

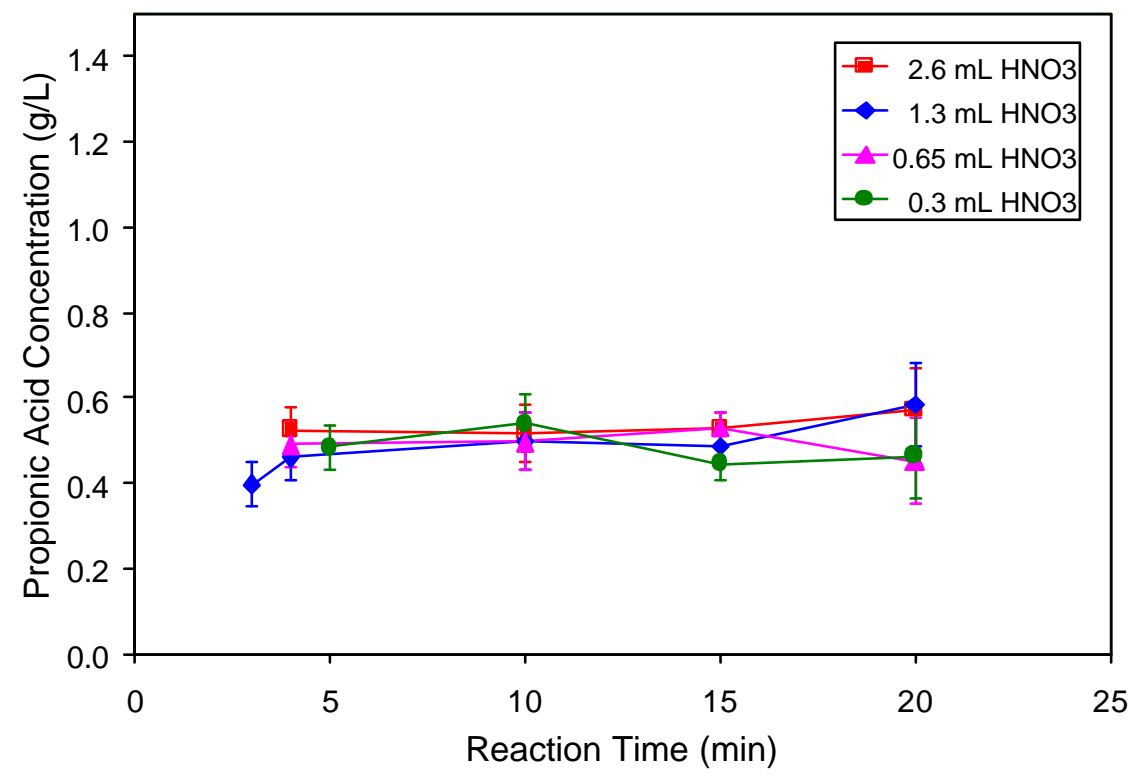

Fig. 9. Propionic acid production as a function of reaction time and amount of nitric acid added. The concentration of propionic acid in the untreated sludge was approximately $0.5 \mathrm{~g} / \mathrm{L}$. 


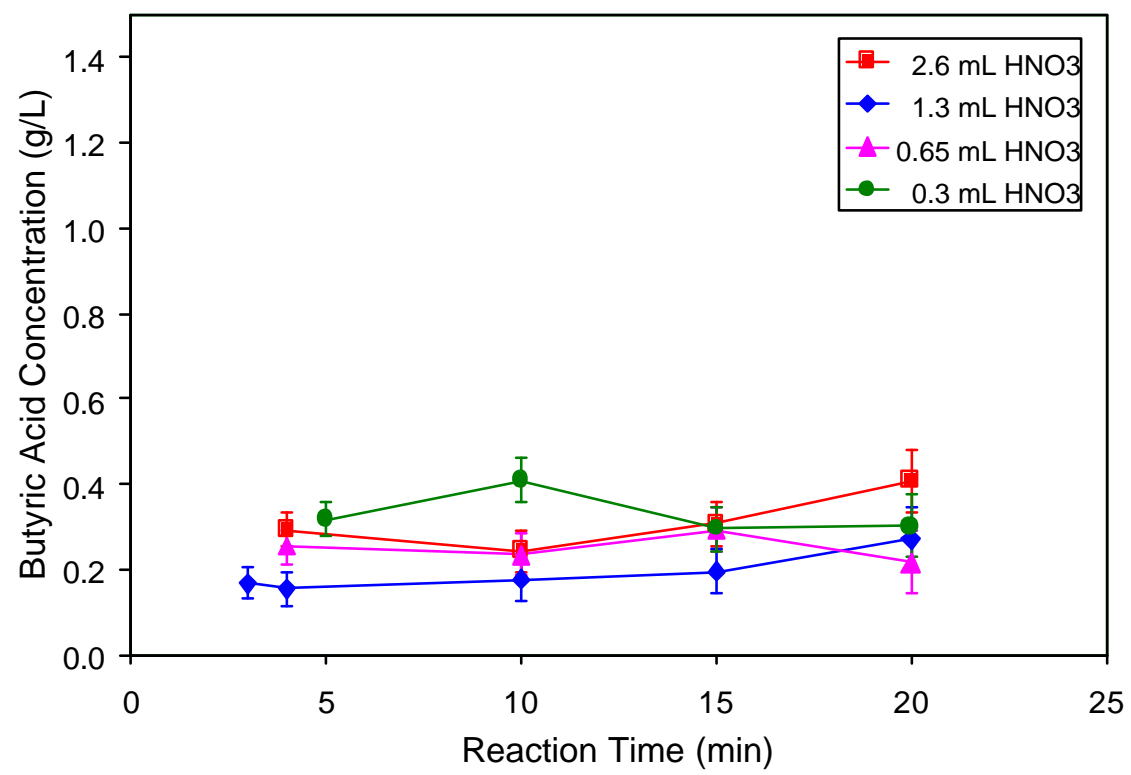

Fig. 10. Butyric acid production as a function of reaction time and amount of nitric acid added. The concentration of butyric acid in the untreated sludge was approximately 0.3 $\mathrm{g} / \mathrm{L}$.

The amount of carbon in the organic acid products could be linked to the amount of nitric acid consumed in the different experiments. It was shown that approximately $0.015 \mathrm{~g} / \mathrm{L}$ of carbon-containing acids were produced for each $1 \mathrm{~g} / \mathrm{L}$ of nitric acid consumed (Fig. 11). The majority of the carbon consumed in the reaction was assumingly converted into carbon-containing gases. The initial 'concentration' of carbon in the reaction mixture was about $16 \mathrm{~g} / \mathrm{L}$ with the sludge contributing $15 \mathrm{~g} / \mathrm{L}$ and the organic acids $1 \mathrm{~g} / \mathrm{L}$.

\section{CONCLUSIONS}

Nitro-hydrolysis of sludge proved a very efficient way of reducing sludge volume, producing a treated solution which contained unreacted solids (probably inorganics such as sand and silt) that settled quickly. Formic acid was one of the main organic acid products of reaction when larger quantities of nitric acid were used in the nitrolysis. When less nitric acid was used formic acid was initially produced but was later consumed in the reactions. The other major organic acid produced was acetic acid which doubled in concentration during the reaction when larger quantities of nitric acid were used. Propionic acid and butyric acid were not produced or consumed in these experiments. 


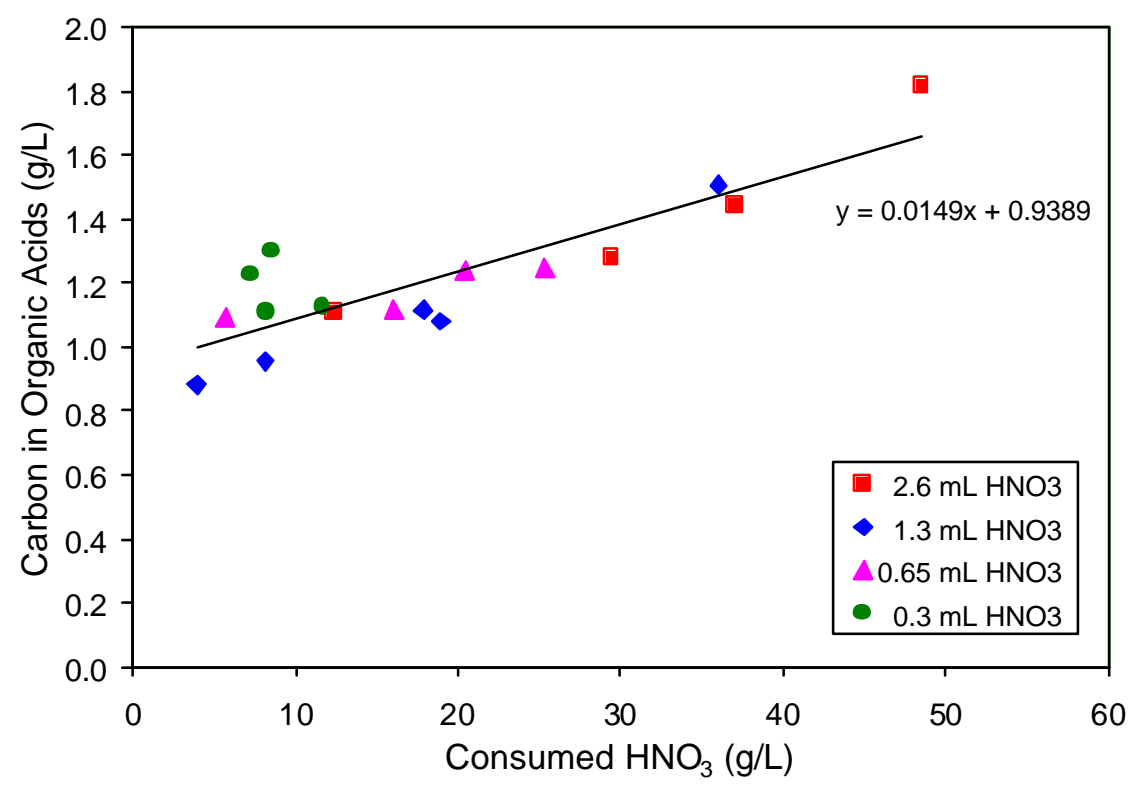

Fig. 11. Yield of carbon in organic acids as a function of the nitric acid consumption.

\section{REFERENCES}

1. Metcalf \& Eddy, Inc., Wastewater Engineering Treatment, Disposal and Reuse, 3rd ed., McGraw-Hill Book Co., New York, 1991.

2. W. Schotte, "Wet Oxidation of Acidified Activated Sludge," U.S. Patent 3,649,534, March 14, 1972.

3. T. T. Poon, C. J. Perilloux, and R. M. Counce, Chemolysis (Nitro-Hydrolysis): A Mass Balance Analysis, The University of Tennessee, 1994.

4. R. B. Helm, "Managing Industrial Sludges and Biosolids," Pollution Engineering 26(13), 34-36 (1994).

5. Chemical Marketing Reporter 258(22), 26-33 (2000).

6. J. K. Taylor, Statistical Technique for Data Analysis, Lewis Publishers, Boca Raton, FL, 1990, p. 48. 
ORNL/TM-2003/3

\section{INTERNAL DISTRIBUTION}

1. J. F. Birdwell, Jr.

2. M. A. Brown

3. R. M. Counce

4. B. H. Davison

5. S. R. Drescher

6. M. A. Karnitz

7. K. T. Klasson

8. B. E. Lewis, Jr.
9. J. D. Randolph

10. S. P. Singh

11. B. B. Spencer

12. J. F. Walker, Jr.

13. Central Research Library

14. ORNL Laboratory Records-RC

15. ORNL Laboratory Records-OSTI

\section{EXTERNAL DISTRIBUTION}

16. B. Alderson, Eastman Chemical Company, P.O. Box 511, Kingsport TN 37662

17. P. R. Bienkowski, Department of Chemical Engineering, University of Tennessee, 419 Dougherty Hall, Knoxville, TN 37996

18. C. C. Churn III, Eastman Chemical Company, P.O. Box 511, Kingsport TN 37662

19. J. C. Collier, Department of Chemical En gineering, University of Tennessee, 419 Dougherty Hall, Knoxville, TN 37996

20. P. D. Frymier, Department of Chemical Engineering, University of Tennessee, 419 Dougherty Hall, Knoxville, TN 37996

21. D. Haseltine, Eastman Chemical Company, P.O. Box 511, Kingsport TN 37662

22. B. D. Hensley, Energy Division, Department of Economic and Community Development, Department of Tennessee, 312 Eight Ave., North, Nashville, TN 37243

23. R. T. Jubin, HQ USEUCOM, CMR 480, Box 591, APO AE 09128

24. C. Oliphant, Energy Division, Department of Economic and Community Development, Department of Tennessee, 312 Eight Ave., North, Nashville, TN 37243

25. C. J. Perilloux, Sabine River Laboratory, DuPont Textiles and Interiors, P.O. Box 1089, Orange TX

26. L. W. Perkins, Department of Chemical Engineering, University of Tennessee, 419 Dougherty Hall, Knoxville, TN 37996

27. R. A. Reimer, Sabine River Laboratory, DuPont Textiles and Interiors, P.O. Box 1089, Orange TX 77631 